\title{
Correlation between selected parameters of planting material and strawberry yield
}

\author{
Marcin Bartczak, Jolanta Lisiecka, Mikołaj Knaflewski
}

Department of Vegetable Crops

Poznan University of Life Sciences

Dąbrowskiego 159, 60-594 Poznań, Poland

e-mail: lisica@up.poznan.pl

\begin{abstract}
The aim of this study was to determine the effect of fresh and dry weight, as well as the number and length of roots and number of crowns of different types of plants, on the yield of strawberry grown for the spring and autumn harvests. Three different types of frigo strawberry plants (waiting bed plants, plug plants, A+ plants) and two strawberry cultivars ('Honeoye' and 'Elsanta') were compared in the experiment. The plants were grown in polypropylene bags in an unheated glasshouse in the years 2002-2005. The correlation coefficients were calculated to estimate the relationship of the strawberry plants' parameters to the yield quantity. An analysis of regression for the plant parameters that most significantly correlated to the strawberry yield was carried out, which determined that the fresh and dry weight of the strawberry plants, crown number, as well as length of roots were positively correlated to the quantity of the strawberry yield. The highest positive correlation coefficient was found for the fresh weight of a whole plant and the lowest one for the number of roots.
\end{abstract}

Key words: crowns, Fragaria $\times$ ananassa, dry weight, fresh weight, roots

\section{INTRODUCTION}

Successful strawberry production depends upon a supply of high quality plants (Radajewska and Aumiller 1995, Le Miere et al. 1998, Perez de Camacaro et al. 2004, Shokaeva 2004, Johnson et al. 2005). According to Gafke et al. (1993), using low quality plants leads to a high loss of yield and is impossible to compensate for.

A number of components have been shown to influence strawberry yield, including the number of leaves (Lacey 1973, Albregts and Howard 1985, Lieten 2000), crown diameter (Hughes 1967, Kramer and Schultze 1985, Lieten 1991, Le Miere et al. 1998, Perez de Camacaro et al. 2004, Johnson et al. 2005, Hochmuth et al. 2006) and initial plant weight (Schrevens et al. 1989, Takeda et al. 2004).

The aim of this study was to determine the effect of fresh and dry weight, as well as number and length of roots and number of crowns of different types of plants, on the yield of strawberry during the spring and autumn harvest.

\section{MATERIAL AND METHODS}

The studies were carried out in the years 2002-2005 at the „Marcelin” Experiment Station belonging to the Poznan University of Life Sciences. The experiment was established in an unheated glasshouse in a split plot design in four replications. The first factor was the type of frigo plant: waiting bed plants, plug plants and A+ plants; the second was the cultivation term: either spring or autumn harvest; and the third factor was the cultivar: 'Honeoye' and 'Elsanta'.

The strawberry plants were planted into polypropylene bags in a density of 7.7 plants $\mathrm{m}^{-2}$. The bags were placed on gutters at the height of $120 \mathrm{~cm}$. The distance between the gutters was $60 \mathrm{~cm}$. The fresh and dry weights of the plants were determined before their planting in the glasshouse. For this purpose, 15 plants of each type were used. Plants were dried at $105^{\circ} \mathrm{C}$ until a constant weight was recorded, and weighed. The length of the root system was measured with a ruler precisely to $1 \mathrm{~mm}$. 
Measurements were done after washing roots off the substrate. The number of roots and crowns of the plants were also counted.

Total, marketable and early yields were determined. The total yield comprised all harvested fruit. Marketable yield consisted of fruit that were healthy, well developed, not damaged by pests or diseases, with calyx and short stipules. Early yield comprised marketable yield harvested in the first $1 / 3$ of the entire harvesting time. Extra quality yield consisted of fruit with a minimum diameter of $25 \mathrm{~mm}$.

The correlation coefficients were calculated to estimate the relationship of the plants' parameters to the yield. For the most important correlations, analysis of regression was computed. Regression equations and their parameters were determined with the computer program Table Curve 2D by SPSS Inc., and with the Statistica program for Windows 5.1 G (edition 97) by StatSoft Inc.

\section{RESULTS AND DISCUSSION}

A significant correlation of fresh and dry weight of the plants, as well as the number and length of roots and number of crowns to total, marketable and early yield was found (Tab. 1). There was a significant effect of the fresh and dry weight of the plants, number of roots and crowns on extra quality yield. However, no effect of root length on extra quality yield was observed.
The highest correlation coefficient $(r=0.80)$ was obtained between plant fresh weight and total yield, as well as marketable yield. Zaliwski (1984) emphasised that stronger plants give higher yield in the first year after planting.

It was also found that total and marketable yields were strongly related to the number of roots and crowns of the plants at planting time, while length of roots had little effect on the yield. According to Larcher (1995), plant productivity depends on photosynthetic production, which is mostly determined by the size of the assimilation apparatus of the whole plant. In the experiments conducted by Schrevens et al. (1989), Bish et al. (1997) and Takeda et al. (2004), the use of larger plants increased the total production of strawberry fruit.

In the presented study, the dry weight of the plants had the greatest effect on the early yield of strawberry fruit, while number of crowns had a smaller influence, and the length of roots was found to have the smallest. Rice and Duna (1986) and Bish et al. (1997) also reported a positive correlation between early yield and plant fresh weight at planting. In this study, extra quality yield was the strongest related to the dry weight of a plant, while the coefficient was the lowest for root length. Regression analysis showed a significant correlation between the initial fresh weight of the plants and the total yield. Linear dependency shows that an increase in fresh and dry weight of plants corresponded to an increase in total yield (Figs 1 and 2).

Table 1. Correlation coefficients between the plant parameters at planting time and yield (mean for spring and autumn harvest)

\begin{tabular}{|c|c|c|c|c|c|}
\hline \multirow[b]{2}{*}{ Yield } & \multicolumn{5}{|c|}{ Correlation coefficients (r) } \\
\hline & $\begin{array}{c}\text { Fresh weight } \\
\text { of a plant }\end{array}$ & $\begin{array}{c}\text { Dry weight } \\
\text { of a plant }\end{array}$ & Number of roots & Length of roots & Number of crowns \\
\hline Total & $0.80 * * *$ & $0.55^{* * *}$ & $0.70 * * *$ & $0.45^{* * *}$ & $0.68 * * *$ \\
\hline Marketable & $0.80 * * *$ & $0.55^{* * *}$ & $0.72 * * *$ & $0.42 * * *$ & $0.67 * * *$ \\
\hline Extra quality & $0.27 * * *$ & $0.42 * * *$ & $0.18 * *$ & 0.08 & $0.29 * * *$ \\
\hline Early & $0.30 * * *$ & $0.60 * * *$ & $0.27 * * *$ & $0.16^{*}$ & $0.52 * * *$ \\
\hline
\end{tabular}

*significant at $\mathrm{p}=0.05 ; * *$ significant at $\mathrm{p}=0.01 ; * * *$ significant at $\mathrm{p}=0.001$

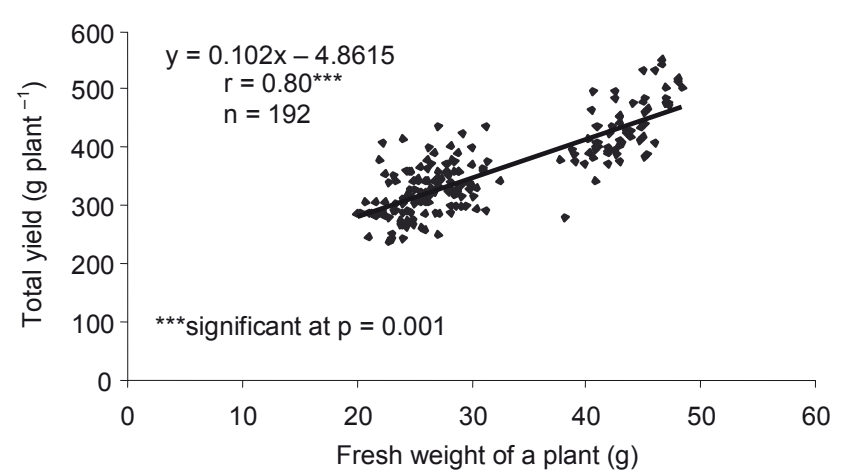

Figure 1. Correlation between fresh weight of a plant at planting time and total yield

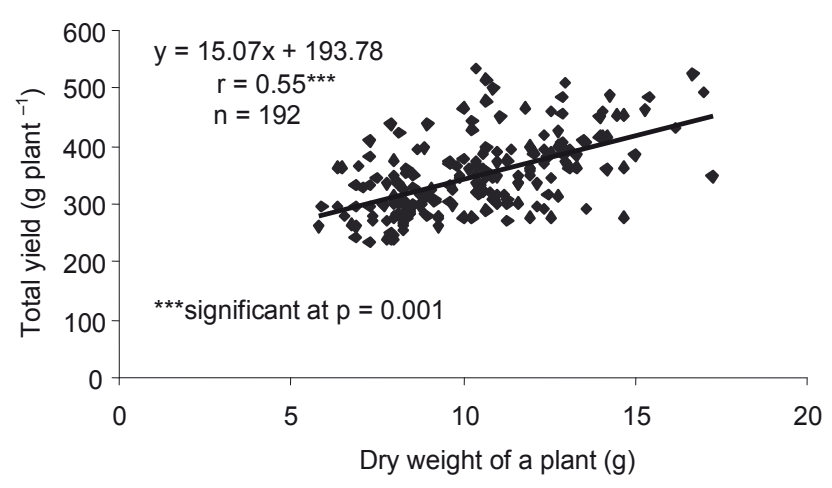

Figure 2. Correlation between dry weight of a plant at planting time and total yield 
Significant linear dependency between the number of roots and total yield was also observed (Fig. 3). Regression analysis showed that an increase in the number of plant roots corresponded to the total yield. A similar correlation between root length and total yield was shown by regression analysis (Fig. 4). A linear dependency between the mean number of crowns and total yield was proved (Fig. 5). An increase in mean crown number corresponded to an increase in yield. According to Kopcewicz and Lewak (2002), bigger organs can store more carbohydrate reserves, which are used by young plants at the beginning of the growing period. Palha et

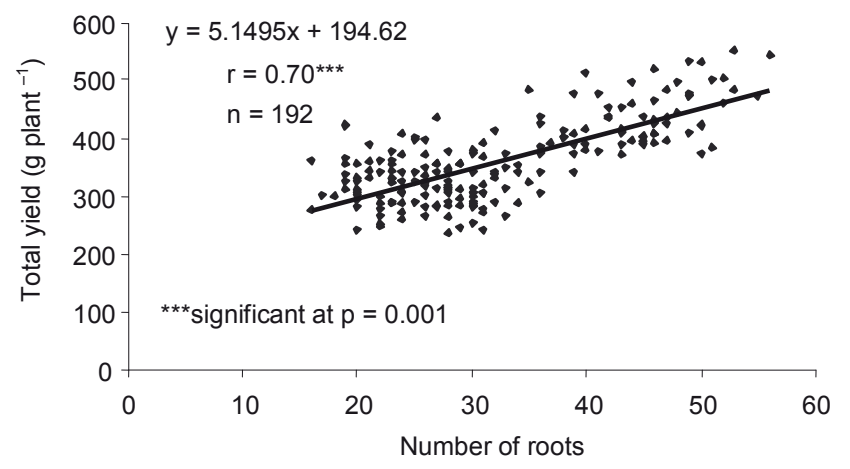

Figure 3. Correlation between number of roots at planting time and total yield

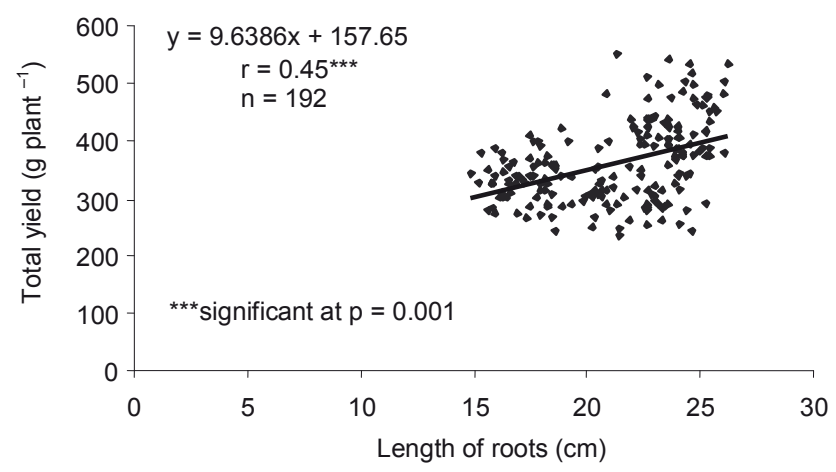

Figure 4. Correlation between length of roots at planting time and total yield

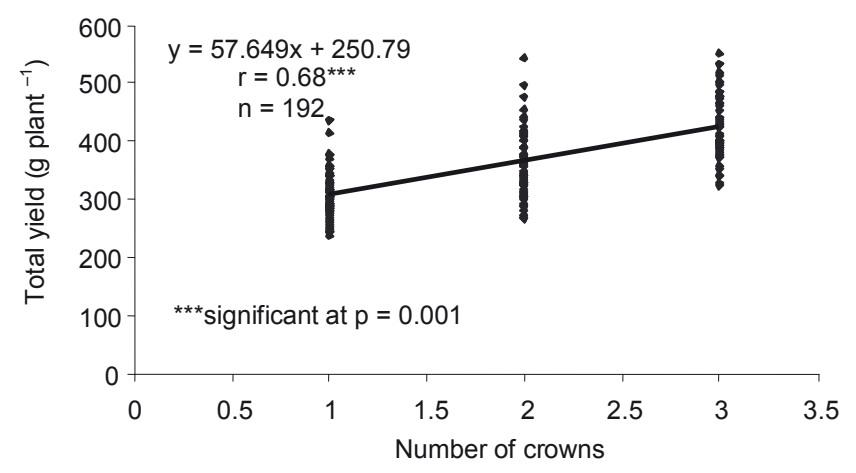

Figure 5. Correlation between number of crowns at planting time and total yield al. (2002) found a positive relationship between early yield and root carbohydrate content of plants at harvest time. In contrast, there was no evidence of correlation between starch and/or carbohydrate content at the time of planting and total yield.

\section{CONCLUSIONS}

1. Fresh and dry weight of strawberry plants, crown number and root length were positively correlated to the quantity of strawberry yield.

2. The highest correlation coefficient was found for the fresh weight of a whole plant.

3. The lowest correlation coefficient was observed for the number of roots.

\section{REFERENCES}

Albregts E.E., Howard C.M., 1985. Correlation of leaf number at transplanting to strawberry fruit yield. Hort. Sci. 20: 415-416.

Bish E.B., Cantliffe D.J., Hochmuth G.J., Chandler C.K., 1997. Development of containerized strawberry transplants for Florida's winter production system. Acta Hort. 439: 461-468.

Gafke F., Kastner R., Greulich E., 1993. Erdbeeranbau unter Glas erfolgreich und lohnend. Gartenbau-Magazin 2(6): 48-49.

Hochmuth G., Cantliffe D., Chandler C., Stanley C., Bish E., Waldo E., Legard D., Duval J., 2006. Containerized strawberry transplants reduce establishment-period water use and enhance early growth and flowering compared with bare-root plants. HortTechnol. 16: 46-54.

Hughes H.M., 1967. The effect of planting time, runner size and plant spacing on the yield of strawberries. J. Hort. Sci. 42: 253-262.

Johnson Ch., Raiford T., Whitley K., 2005. Initial crown diameter of transplants influences marketable yield components of two strawberry cultivars in annual hill production system. Int. J. Fruit Sci. 5: 23-29.

Kopcewicz J., LewaK S., 2002. Fizjologia roślin. PWN, Warszawa: 806.

Kramer S., Schultze W., 1985. Der Einfluß der Jungpflanzenqualität auf den Ertrag der Erdbeere. Gartenbau 32(4): 115-117.

LACEY C.N.D., 1973. Phenotypic correlations between vegetative characters and yield components in strawberry. Euphytica 22: 546-554.

Larcher W., 1995. Physiological Plant Ecology. SpringerVerlag, Berlin: 69.

Le Miere P., Hadley P., Darby J., Battey N.H., 1998. The effect of thermal environment, planting date and crown size on growth, development and yield of Fragaria $\times$ ananassa Duch. J. Hort. Sci. Biotechnol. 73: 786-795.

Lieten F., 1991. Dubbel geplante frigoplanten vervangen wachtbedplanten niet. Fruitteelt 4(10): 36-37. 
LiETEN F., 2000. Recent advances in strawberry plug transplant technology. Acta Hort. 513: 383-388.

Palha M.G.S., Taylor D.R., Monteiro A.A., 2002. The effect of digging date and chilling history on root carbohydrate content and cropping of 'Chandler' and 'Douglas' strawberries in Portugal. Acta Hort. 567: 511-514.

Perez de Camacaro M.E., Camacaro G.J., Hadley P., Dennett M.D., Battey N.H., Carew J.G., 2004. Effect of plant density and initial crown size on growth, development and yield in strawberry cultivars Elsanta and Bolero. J. Hort. Sci. Biotechnol. 79: 739-746.

Radajewska B., Aumiller A., 1995. Wpływ jakości sadzonek na plonowanie kilku odmian truskawki w szklarni nieogrzewanej. Mat. I Ogólnopol. Seminarium Pracowników Katedr Sadownictwa „Postęp w intensyfikacji upraw sadowniczych”, Poznań-Przybroda, 27-28 wrzesień: 243-248.

Rice R.P., Duna N., 1986. The effect of initial plant size on yield components of winter-planted strawberries in coastal Lebanon. J. Hort. Sci. 61: 201-203.

Schrevens E., Lamberts D., Lettani L., 1989. Intensive hydroponical cropping system for strawberries in greenhouses. Acta Hort. 265: 275-280.

ShoKaEva D., 2004. Factors influencing marketable yield and berry size in short-day strawberry varieties in two fruiting seasons. J. Fruit Ornam. Plant Res. 12: 159-166.

TAKEDA F., HoKanson S.C., EnNs J.M, 2004. Influence of daughter plant weight and position on strawberry transplant production and field performance in annual plasticulture. HortScience 39(7): 1592-1595.
ZALIWSKI S., 1984. Intensywna produkcja owoców jagodowych i leszczynowych. PWN, Warszawa: 560.

\section{ZALEŻNOŚĆ MIĘDZY WYBRANYMI CECHAMI SADZONEK TRUSKAWKI A WIELKOŚCIĄ PLONU}

Streszczenie: Celem badań była ocena zależności między niektórymi cechami sadzonek a wielkością plonu truskawki. Uwzględniono świeżą i suchą masę całej sadzonki, liczbę i długość korzeni, a także liczbę koron trzech rodzajów sadzonek frigo (zagonowe, doniczkowe i $\mathrm{A}+$ ). Badania prowadzono na dwóch odmianach 'Honeoye' $i$ 'Elsanta' uprawianych w workach polipropylenowych na wiosenny i jesienny zbiór w nieogrzewanej szklarni w latach 2002-2005. Dla oceny zależności pomiędzy cechami sadzonek i wielkością plonu wyliczono współczynniki korelacji. Dla najbardziej istotnie skorelowanych cech wykonano analizę regresji. Stwierdzono, że świeża i sucha masa sadzonek, liczba koron i długość korzeni były pozytywnie skorelowane z wielkością plonu. Największe współczynniki korelacji znaleziono dla świeżej masy sadzonek a najmniejsze dla liczby korzeni. Im większa była świeża masa sadzonek, tym większy uzyskano plon.

Received January 21, 2009; accepted April 14, 2010 